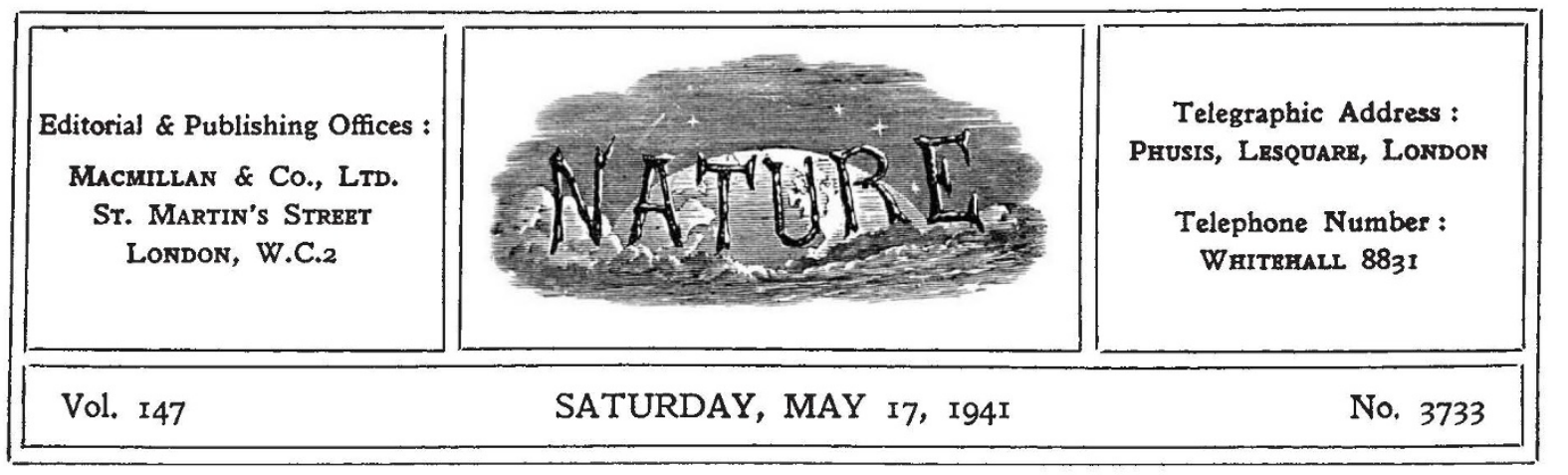

\title{
THE SELECT COMMITTEE OF NATIONAL EXPENDITURE
}

W HILE the statement on science and the national effort which Lord Hankey made in the House of Lords on April 2 (see Nature of April 12, p. 432) of necessity adds little to an earlier statement by Lord Chatfield last year, it gives an admirable reply to certain criticisms of the use being made by the Government of our scientific man-power, and with little supplementing could well be used by the scientific worker to educate public opinion as to the part which science is playing in our war effort. It was, of course, well-nigh impossible for Lord Hankey to cover the whole field in any detail in the time at his disposal, but there are at least two respects in which from the point of view of educating public opinion his statement might perhaps have been amplified.

In his reference to the achievements of Nazi Germany in the field of science, Lord Hankey contented himself with the assertion that our men of science are at least as good as his. Without adulation of our own achievements in this respect Lord Hankey might well have pointed out that the domination of science by the State under the Nazis and the proscription of freedom of thought and investigation, apart from racial persecution and discrimination, have not only robbed Germany of many of her ablest workers, but have also made German science static. As Mr. W. Kæmpffert points out in an article "Science in the Totalitarian State" , while science can exist in a totalitarian regime, it will be a frozen science. Science can only be a powerful social force for good when the individual worker is permitted to enjoy the fundamental freedom of democracy-to work without intellectual restraint.

* Forriga Affairs, January, 1941.
Lord Hankey might well therefore have referred more explicitly to the way in which the existence of creative science and an independent scientific outlook are bound up with the existence of democracy and have pointed to the decadence of science in Nazi Germany, as Dr. C. J. T. Cronshaw did in his recent address before the Society of Dyers and Colourists. Dr. Cronshaw made the important point that Germany is fighting this war on the technical progress and skill of a generation which is running out and which in calibre, training and experience is not by great lengths matched by succeeding generations. Bias and prejudice had destroyed progress.

Reference to the work of the Select Committee of National Expenditure would also have been appropriate and useful. There are in fact few bodies which are doing more to inculcate a scientific outlook and approach to the national effort than this Committee in its admirable series of reports. Its searching but constructive criticism is designed not merely to eliminate waste but also to encourage that impartial and comprehensive view of affairs which is of the essence of the scientific spirit. Tribute to such work in Lord Hankey's statement would not have been more appropriate than deserved. The Scientific Advisory Committee takes a narrow view of its functions if it fails to recognize the assistance it is receiving both directly and indirectly from this Select Committee.

The value of the latter's work is indeed cumulative, and the very existence of such a committee is striking evidence of the inherent healthiness of the democratic system and its capacity to rectify weaknesses or abuses, given the will or driving 
power. The impartial but severe and searching criticism of the Sub-Committee on Air Services, in the Select Committee's Ninth Report, of the Air Ministry's practice of price contracts for the preparation and construction of aerodromes, the equally severe condemnation by the Sub-Committee on Supply Services, in the Seventh Report, of the Ministry of Works and Buildings for the absence of unified control over constructional work, and also the strictures, amounting almost to censure, on the Ministry of Transport and other Government departments in the Eighth and Tenth Reports would not be possible under a totalitarian regime, with its stifling of independent judgment and impartial analysis. Such constructive criticism is at once the strength and opportunity of democracy, provided only its leaders and institutions are capable of profiting by criticism and applying it without prejudice and with firm resolution to the remedying of the weaknesses disclosed.

These latest reports from the-Select Committee, no less than the earlier reports, are in fact a searchlight on the position of and opportunity for scientific management in Great Britain. There are few factors more vital to the efficient conduct of our war-effort than scientific management, and if in his recent speech in the House of Commons Mr. Bevin did less than justice to some of the factors on the labour side which impede production, his indictment of management was fully justified in many quarters and is substantiated by evidence in these reports. There can be no place in our war-effort for management or directorates which wilfully ignore dearly purchased experience with regard to hours of work, the value of canteens and other problems in industrial psychology in which in the last twenty-five years so much work has been done by the Industrial Health Research Board, the National Institute of Industrial Psychology and by other bodies.

Many of the weaknesses which call forth the severest criticism of the Select Committee are due fundamentally to neglect of such experience or of established principles of management. It is indeed startling to find that it is still necessary to put emphasis on supervision, whether at the top to secure unified control, by the appointment of one man with the maximum authority to be in charge of each building or group of buildings in course of construction, or in the provision of skilled supervisory staff on the site. The neglect of management principles and experience thus revealed in the Seventh Report is exactly parallel with similar criticism of the Air Ministry's failure to inquire into the most economic management of labour and materials on the site, or to supply adequate supervision in aerodrome construction, and with the neglect in the exchange of technical knowledge which is the subject of comment in the same report.

The importance attached by the Sub-Committee on Air Services to the pooling of ideas and knowledge has a direct bearing on Lord Hankey's state ment. It indicates at least one point in which there is some hiatus in the application of scientific and technical knowledge to the war-effort of the nation. A further point is indicated in the Sixth Report of the series, in which the Sub-Committee on Trade, Agriculture and Economic Warfare reviews the work of the Ministry of Agriculture and Fisheries.

The Sub-Committee has been impressed by the statement of witnesses that what is required to improve the standard of British farming is not so much further research work and the development of new scientific methods as the translation into practice of certain simple lessons already clearly taught by scientific study and by the experience of progressive farmers. This is largely the task of scientific exposition, to which the P E P Report on Agricultural Research in Great Britain directed particular attention in November 1938, and which was the subject of some of its most important recommendations. The great need is to find sufficient numbers of men combining knowledge with practical experience to give this instruction and advice by personal visits.

Beyond this, however, the Sub-Committee points out that action is required to ensure getting full value from the County War Committees' powers. Instructions should be issued to ensure that valuable data resulting from the Committees' experience are recorded and collated, that the experience gained and ideas developed by one Committee are made available to others, and that the fullest advantage is taken of experience gained from direct farming by the County Committees. Considerable importance is also attached to the strengthening of the Economic Intelligence Division of the Ministry, both in staff and in authority, as the chief safeguard for continuity of policy and for holding the balance between contending enthusiasts.

These recommendations, designed to facilitate all the resources of science being readily available for the solution of war-time problems, well illustrate the way in which the Select Committee's reports supplement the picture of science and the national 
effort given by Lord Hankey. There is, however, one further aspect, particularly stressed in this Sixth Report, to which Lord Hankey referred, in which the reports and the statement are complementary. Lord Hankey referred finally to the way in which British men of science and the scientific resources of the Empire and of the United States are building scientific equipment destined to play an ever-increasing part not merely in our wareffort but also in the period of reconstruction that must follow. The Select Committee in its Sixth Report stresses the importance, as the War proceeds, of shaping plans for post-war policy with progressive definition.

It is pointed out that the two issues-war-time food production policy and long-term agricultural policy-are closely interlocked. A complete review of the opportunities for improving the fertility of the soil would be valuable both for war and for post-war purposes, particularly a review of what can be done to improve drainage. Again, the general method for giving a sound foundation to the agricultural industry might well be the same for both the war and the post-war periods, although their detailed application might differ. The essential need for creating confidence in post-war policy as a measure for encouraging the war effort means that in agriculture especially the two must to some extent be considered together.

To this end the Report suggests that the Ministry might collect and prepare adequate material, to be issued in due course as a White Paper, so that when the appropriate time comes Parliament would have before it the basis for a comprehensive plan for maintaining, after the War, a healthy and wellbalanced agriculture as an essential and permanent feature of national policy, in accordance with the Ministerial statement of November 26. It is only by continuity of policy that confidence can be created and waste avoided.

Similarly the investigation of deficiencies in the system for the distribution of vegetables which may both lead to waste and discourage production should yield results as valuable after as during the War. Again a comprehensive plan for crop production must take account not only of agricultural conditions and the need for balanced production with proper rotation of crops but also of the nutritional requirements of the country and the nature and quantity of imported food supplies which will be available. The Scientific Committee which has been set up by the Government to advise upon these problems may well lead to marked improvements in the nutrition of the nation after as well as during the War, and here again, the Select Committee observes, it may be possible to pass, as experience is gained, from the stage of tentative direction to the formulation of a definite and comprehensive plan.

These reports of the Select Committee accordingly make heartening reading in days when sterner sacrifices and more strenuous efforts are being demanded of every citizen. They show that scientific minds are resolutely probing into weaknesses and inefficiencies in our war-effort and pointing the way to eliminate them. Still more, they afford solid and renewed grounds for eonfidence that the sacrifices and effort demanded of us will not be in vain. It is not merely that obstacles to progress are being loosened and the way cleared for advance. In the midst of our war-effort there are slowly but progressively emerging the lines of policy and the plans which will shape a new era in which science may prove itself a growing social force for good in the democracies it has helped to victory.

\section{THE FEEDING OF LIVESTOCK}

The Principles and Practice of Feeding Farm Animals

By E. T. Halnan and Frank H. Garner. Pp. $x+359+8$ plates. (London, New York and Toronto : Longmans, Green and Co., Ltd., 1940.) 15s. net.

THE stress of totalitarian war has quickly revealed the fundamental instability of systems of livestock husbandry which are largely dependent upon supplies of imported feedingstuffs. In an industrialized State, concerned to maintain a large export trade and with a large investment of capital in the less-developed regions of the world, it is inevitable that the national agricultural economy should provide for a considerable absorption of imported grain, oil-seeds and other primary produce. If this absorption has developed beyond the limits of security for war conditions, the blame, if blame there be, cannot 